DEVELOPING ENGLISH SPEAKING MATERIALS FOR STUDENTS OF BEAUTY STUDY PROGRAM AT VOCATIONAL SCHOOL

\begin{abstract}
AN ARTICLE
Submitted in Partial Fulfillment of the Requirements for the Degree of Sarjana Pendidikan
\end{abstract}

By:

EKA WINDA SARI

Registration Number: 2132121011

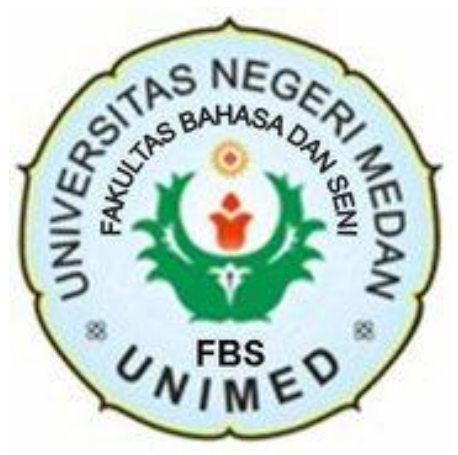

ENGLISH AND LITERATURE DEPARTMENT

FACULTY OF LANGUAGES AND ARTS

MEDAN STATE UNIVERSITY

2018 


\title{
ARTIKEL
}

\section{DEVELOPING ENGLISH SPEAKING MATERIALS FOR STUDENTS OF BEAUTY STUDY PROGRAM AT VOCATIONAL SCHOOL}

\author{
Disusun dan Diajukan oleh: \\ Eka Winda Sari \\ Registration Number: 2132121011 \\ Telah diverifikasi dan dinyatakan memenuhi syarat \\ untuk diunggah pada jurnal online \\ Medan, Januari 2018
}

Menyetujui

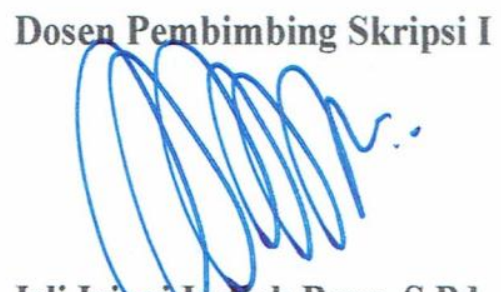

Isli Iriani Whdiah Pane, S.Pd., M.Hum. NIP. 197908022005012003
Dosen Pembimbing Skripsi II

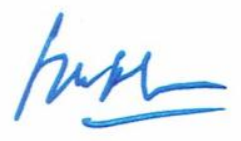

Dra. Sortha Silitonga, M.Pd. NIP. 195309241979112001

Ka. Program Studi

Pentidikan Bahasa Inggris<smiles>CCCCCC1CCCCC1C</smiles>

Nora Ronita Dewi, S.Pd., S.S., M.Hum.

NIP. 198005222008122003 


\title{
DEVELOPING ENGLISH SPEAKING MATERIALS FOR STUDENTS OF BEAUTY STUDY PROGRAM AT VOCATIONAL SCHOOL
}

\author{
* Eka Winda Sari \\ ** Isli Iriani Indiah Pane \\ ** Sortha Silitonga
}

\begin{abstract}
This study aims to develop appropriate English speaking materials for grade $\mathrm{X}$ students of Beauty Study Program at SMK Negeri 1 Beringin. This study was conducted by Research and Development (R \& D) design through six phases; gathering information and data, analyzing data, designing new materials, validating new materials by experts, revising, and final product. The subject of this research was grade X students of Beauty study program consisting of 19 students. The instrumentations for collecting data were questionairre and interview. After analyzing the data, the writer got the students' needs. The data were gathered by administering interview to the teacher and distributing the questionairre to 19 respondents to get the students' needs. The result of questionairre and interview prove that the students need English speaking materials which appropriate to their major that is Beauty study program. Thus, developing English speaking materials consist of three units, they are welcome to our beauty salon, complimenting and showing care, and congratulations on your achievement. The products have been validated by experts. The average scores are 4.3 from English Lecturer and 4.5 from English Teacher. It means that the developing materials categorized as relevant or appropriate for Grade X Students of Beauty study program.
\end{abstract}

Keywords: English speaking materials, Beauty study program, Research \& Development $(R \& D)$,

\footnotetext{
*Graduate

** Lecturer
} 


\section{INTRODUCTION}

\section{Background of the Study}

In Indonesia, English has been used as a foreign language. English consists of four skills which have to be mastered by the students, they are listening, speaking, reading and writing. The learners are required to comprehend (listening and reading) the language and produce (speaking and writing) the language. In teaching the language, between comprehending the language as well as producing the language are exactly have relationship.

One of the education institutions which includes English as a compulsory subject is the vocational high school (SMK). Vocational high school is an educational institution which develops students' skills in order to prepare them mastering specific jobs after they graduate based on their skill programs. English for vocational high school is supposed to be taught to the students specifically based on the nature of their vocation so that they can use their English proficiency to continue their education or to compete in their workplace later on. In order to fulfill the expectation, the students have to master the four basic language skills of learning English including listening, speaking, reading and writing skills. In this case, the students are expected to be able to master one of skills to produce language which is known as speaking skill.

Speaking is considered to be one of the four macro skills necessary for effective communication in any language according to most research, particularly 
when speakers are not using their mother tongue. As English is universally used as a means of communication, especially on the Internet, English speaking skills should be developed along with the other skills so that these integrated skills will enhance communication competence (Yulia:2013). Speaking can also serve one of two main functions: transactional (transfer of information) and interactional (maintenance of social relationships) (Brown and Yule, 1983:3).

In mastering English speaking skill, the participants in the classroom (teacher and students) are required to build an effective communicative atmosphere during the teaching and learning process. For example, designing effective activities such as role play, turn taking, or conversation based on the students' major. In contarst, Taher \& Rahmatollah, in (Journal of Education and Practice, 2012) state that most of the language teachers who are to run conversation courses still devote much of the class time immersing the students with non-communicative activities. So, based on the case above, the most important materials in speaking classroom that have to be developed in order to stimulate the students' enthusiasm is transactional speaking.

According to Richards, 1990, "Transactional uses of language are those in which language is being used primarily for communicating information" (p.54). In order to interact with the customer successfully, students need to be able to give responses or informations, so that is why the development of transactional speaking materials is urgently needed by the students. Transactional materials also perform interactions which have an outcome. The learning outcomes can be seen from the 
students' succeed in being involved with the customers in giving service, responding customers' demand, offering beauty treatments in a multiplicity of situations due to their duty.

In contrast, based on the observation done toward the beauty students at SMK Negeri 1 Beringin, it was found that students' speaking skills didn't reach the competency; the students still get difficulties in doing conversation. It was also difficult for them to express and even to understand the transactional conversation and text in the book. Moreover, it was found that the students use the English textbook which is published by the Ministry of Education and Culture, unfortunately the textbook is also used by the general high school. It can be seen from its cover which is written "Bahasa Inggris - SMA/MA/SMK/MAK Kelas X Semester 1". The English speaking materials which the students learn are still general English. The contents and topics of the English speaking materials are not specific with the beauty program. The speaking materials like: “Guessing Games: Who Am I?”,"Let's play scissors, rock, and paper", "Make up a short dialogue for the following situations (You plan to do the Biology project at the library after school. You ask your best friend to do it together with you)"are not related to the students' needs and major. Exactly, developing English for Specific Purposes (ESP) is intended to improve the students' skill especially for students at vocational secondary school absolutely needed. It is supported by Hutchinson and Waters (1987) who stated that ESP materials focus on the learner, so the clear relevance of the English course to their 
needs would improve the learners' motivation and thereby make learning better and faster. In short, this opinion state that by providing specific English speaking materials for beauty students, it is expected that it can increase the students' motivation in learning English.

Based on some findings above, speaking materials which are related to beauty students will be developed in order to meet the students' need in relation to their major. Speaking materials are chosen to develop by considering the facts that the materials given to the students are not relevant whereas speaking skill should be mastered by them as students of beauty program. English speaking materials for the first grade students of SMK Negeri 1 Beringin will be developed and hopefully can support the teaching and learning process of speaking in order to improve and develop the students' speaking skill for the students' need in the future.

\section{RESEARCH METHODOLOGY}

The research was conducted by using the Research and Development (R\&D). Educational R \& D is a development model in which the findings of research are used to design new products and procedures, which are systematically field-tested, evaluated, and refined until they meet specified criteria of effectiveness, qualitiy, or similar standard Borg \& Gall (2003: 569). Borg and Gall (2003: 572) state that if you plan to do and $\mathrm{R} \& \mathrm{D}$ project for a thesis or dissertation, it is best to undertake a small-scale project that involves a limited amount of original instructional design. So, 
in this research, the ten stages of $\mathrm{R} \& \mathrm{D}$ were simplified into six stages because it depends on the research needed, those are : 1) Gathering data and information, 2) Analyzing Data, 3) Designing first draft of material, 4) Validating by Experts, 5) Revising, and 6) Final product.

The research place was at SMK Negeri 1 Beringin which consist of 19 students of Beauty study program. The source of data was curriculum, syllabus, existing materials, teachers' interview and students' questionnaires as qualitative data. The questionnaires and interview were the instruments of research that analyze descriptively.

In collecting the data the writer used questionnaires and interview. The first, the writer observed the syllabus and material, analyze the basic competence, students' worksheet, and the book. The second the writer did interview section to the English teacher to get information about students' problem which was faced in learning English especially speaking, and also about the materials. The third, the writer gave the questionnaires to the students in order to get information about students' need in learning English. In this section the writer shared the questionnaire. So, the writer can get information toward students' need, students' problem in learning English, and also their interest in speaking. 
The flow chart of developing the materials

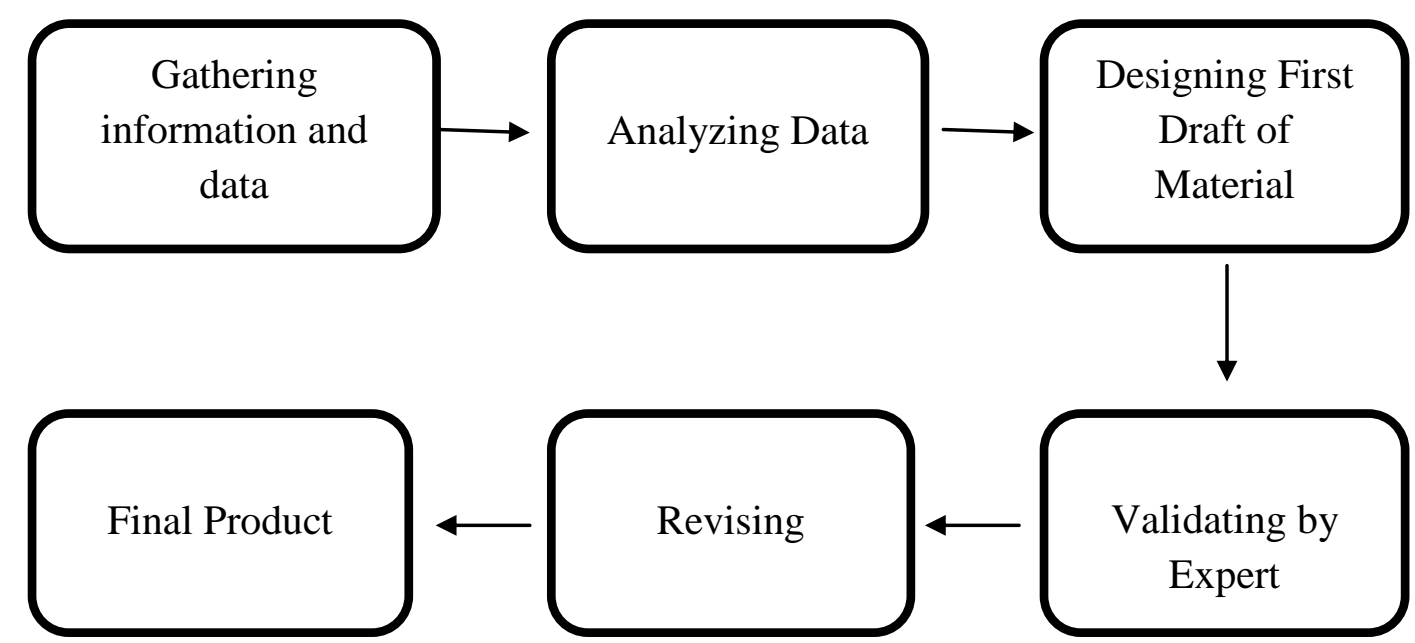

Figure 1.1 The flow chart of developing the materials

\section{MATERIALS DEVELOPMENT}

The aim of this study was to develop appropriate English speaking materials for grade X students of Beauty study program at SMK Negeri 1 Beringin. In order to identify the needs of students of Beauty study program, the writer administered the questionnaire to the students and did the interview to the English teacher. There were 20 questions that were answered by the students. It was the target needs and learning needs of the students.

Target needs is what the learners need to do in the target situations. It was consisted the term of necessities, lacks, and wants. In term of necessities, most of the students demand to master in speaking skill and the English materials were about 
beauty. The lacks, most of the students were weak in speaking skill because they were lack of vocabulary and also less of activities to support their practice in the classroom. In term of wants, most of the students wanted English can help them to communicate fluently. Based on this result, the writer decided to make a topic in each unit related to Beauty context.

The next part is learning needs. The students' learning needs were found in the items which are categorized as input, procedure and setting, learners role and teacher role. The need analysis result showed that the students preferred dialogue as the input of speaking, in term procedure, various activities in learning English was chosed as speaking activity. Furthermore to improve their vocabulary, the students wanted the materials related term to their major. For pronounciation activity, repeating the teacher's pronounciation is the most chosen. In term of setting the students preferred to do the task of speaking in learning process into paired consisting of two people, they wanted the level of difficulties for each lesson activity in the speaking materials have a various from the easiest to the most difficult.

After the needs analysis had been conducted, the next step was formulating a course grid and wrote the first draft of the speaking materials. The results of need analysis were used as a basis to develop the course grid. The speaking materials contain of three units, those are Welcome to Our Beauty Salon, Complimenting and Showing Care, and Congratulations on Your Achievement. Each unit consists of 3 sections namely, Let's Start, Let's Practice, and Closing up (Language Reference). 
As Hutchinson and Water (1987) say that good materials should cover: input, language content, language focus and task. So, the structure of the course book will be organized by combining those elements and task framework. The task framework are consists of three main phases:

1. Pre-task: introducing topic and task prepares learners to perfom tasks in ways that promote acquistion. It can be done through: pictures, brainstorm words associated with the topic, they are useful to activate students' knowledge and direct the students to the task.

2. Task cycle: offers learners the chance to use whatever language they already know in order to carry out the task and then to improve their language under the teacher's guidance while planning their reports on the task.

There are three components of a task cycle:

- Task: learners use whatever language they can master, working simultaneously, in pairs or small groups to achieve goals of the task.

- Planning: learners plan their reports effectively and maximize their learning opportunities.

- $\quad$ Report: is the natural condition of the task cycle. In this stage learners tell the class about their findings.

3. Post-task/ language focus: provides an opportunity for students to reflect on their task and encourages attention to form, in particular to problematic forms which demonstrate when learners have accomplished the task. 
Then, the structure of the English speaking materials are formulated as follows:

a. Title, it was a label of information that described in the content of materials.

b. Objective, it was goals that the students should achieved when using the speaking materials as source of learning. By describing the goals the students motivated in teaching and learning process.

c. Starting up, was played a number of role:

- It created a context of knowledge for the comprehension of the input

- It activated the students' minds and gets them thinking

- It revealed what the students already know in terms of knowledge and content.

d. Let's practice, this section contains several tasks that need to be done by the students, the tasks were designed in order to help and ease the students to promote their speaking skill.

e. Closing up (Language focus and language reference), this section contains information about the language form that relate with the grammar, language function and sentence construction.

The next step was expert judgment process. The materials were evaluated by two experts. The criteria for expert judgment were based on the BSNP standard (Contents, language use, methodology and layout). In the process of experts judgments, there are some mistake should be replace, such as grammatical, spelling, and the vocabularies. Therefore, to get the quality of the product, the writer gave it to 
the validator to be validated. The validators came from and English Lecturer from State University of Medan that was Prof. Dr. Amrin Saragih, M.A., Ph.D., as the first validator and an English Teacher from SMK Negeri 1 Beringin that was Adinda Zoraya Alvin, S.Pd., M.Hum., as the second validator. As the result from the first validator evaluation got 4.3 or $86.2 \%$ (Relevant). Beside that from the second validator evaluation also got 4.5 or $90.3 \%$ (Relevant). Thus, the final draft or the developed English speaking materials were valid and appropriate to be used as learning materials for grade $\mathrm{X}$ students of Beauty study program.

\section{CONCLUSION AND SUGGESTIONS}

\section{The Conclusion}

1. Based on the need analysis from the questionnaire and the interview, it is concluded that the students of Beauty study program in Grade X at SMK Negeri

1 Beringin needed the appropriate English Speaking materials. The English speaking materials were developed in order to increase their knowledge about how the way to communicate and interact with customer or colleague related to their career which can support their career in the future.

2. The speaking materials needed by the students were relevant with their needs where the topics or contents used in the course book were relevant and useful in 
the work situation are: Welcome to our Beauty salon (Introducing), Compliment and showing care, and Congratulations on your achievement (congratulating).

3. The score of validation from the first validator was 4.3 or $86.2 \%$ and it was categorized as relevant and the score of validation from the second validator was also 4.5 or $90.3 \%$ and it was categorized as relevant. It means that, the materials were valid and appropriate to use as learning materials for students of Beauty study program for Grade X at SMK Negeri 1 Beringin.

\section{The Suggestions}

There are three suggestions that the writer gives, they are:

\section{Teacher}

In teaching, teacher should consider the students' needs in choosing the learning materials. The learning process can be successfull if the teacher can give the materials related to the students' program and also the teacher can apply "English for Specific Purposes" approach to apply in teaching English. The new materials in this study has validated in terms of relevancy, contents, layout and linguistic feature by an Esp expert, and the result showed that it was good, relevant and feasible, so it was suggested for the English teacher to use this material to increase the students' speaking skill easier and effectively. 
2. Students

Students can use the materials developed in learning and try to find the materials related to their study program from the internet and the other books, if the existing materials provided are not appropriate to Beauty program.

3. Other Researcher

Other researchers are expected to be able to develop an English learning materials, especially speaking skill for other study programs which have the problems with the availability of appropriate English learning materials

\section{REFERENCES}

Bahrani, T. \& Solatni. 2012. Journal of Education and Practice: How to Teach Speaking Skill. ISSN: 2222-1735. Vol. 3, No. 2.

Brown, G., \& Yule, G. 1983. Teaching the Spoken Language. Cambridge: Cambridge University Press.

Gall, M.D., Joyce, P.G., Walter, R.G. 2003. Educational Research: An Introduction. United State of America: Pearson Education.

Hutchinson, T. \& Waters, A. (1987). English for Specific Purposes: A learningcentered approach. Cambridge: Cambridge University Press.

Morozova, Y. 2013. Translation Journal: Methdos of Enhancing Speaking Skills of Elementary Level Students. Vol. 13, No. 4.

Richards, J.C \& Rodgers, T.S. 2001. Approaches and Methods in Language Teaching. Cambridge. Cambridge University Press. 